\title{
Pengaruh Pembelajaran Kooperatif tipe STAD dengan Bantuan Komputer terhadap Hasil Belajar Fisika Siswa Kelas X SMA Negeri 1 Parigi
}

\author{
Arif, Unggul Wahyono dan Syamsu \\ ariflahaming@gmail.com \\ Program Studi Pendidikan Fisika FKIP Universitas Tadulako \\ Jl. Soekarno Hatta Km. 9 Kampus Bumi Tadulako Tondo Palu - Sulawesi Tengah
}

\begin{abstract}
Abstrak - Penelitian ini bertujuan untuk mengetahui ada tidaknya pengaruh pembelajaran kooperatif tipe STAD dengan bantuan komputer terhadap hasil belajar fisika siswa kelas X SMA N 1 Parigi. Metode yang digunakan adalah kuasi eksperimen dengan the non equivalen preetest-postest design. Populasi penelitian ini adalah seluruh siswa kelas X IPA SMA Negeri 1 Parigi. Pengambilan sampel dilakukan secara purposive sampling dengan sampel penelitian adalah kelas X IPAa sebagai kelas kontrol dan kelas X IPAb sebagai kelas eksperimen. Instrumen penelitian berupa tes pilihan ganda yang telah divalidasi oleh validator dan telah diuji coba lapangan. Peningkatan rata-rata $\mathrm{N}$-gain pada kelas eksperimen adalah $12,81 \%$ sedangkan pada kelas kontrol adalah $11,65 \%$. Nilai signifikansi hasil uji hipotesis diperoleh $t_{\text {hitung }} \geq t_{\text {tabel }}$ atau $4,80 \geq 2,01$ sehingga $H_{1}$ diterima dan $\mathrm{H}_{0}$ ditolak. Hasil ini menunjukkan bahwa terdapat pengaruh pembelajaran kooperatif tipe STAD dengan bantuan komputer terhadap hasil belajar fisika siswa kelas X SMA Negeri 1 Parigi.
\end{abstract}

Kata Kunci : Pembelajaran Kooperatif Tipe STAD, Bantuan Komputer, Hasil Belajar Fisika

\section{PENDAHULUAN}

Sains adalah pengetahuan yang telah disusun secara sistematik, terorganisir, didapatkan melalui observasi dan eksperimentasi serta bermanfaat bagi manusia. Mengacu kepada pengertian ini, jelas bahwa fisika harus diawali dengan melakukan observasi dan eksperimentasi, yang berarti sangat mengutamakan proses tentang bagaimana cara memperoleh pengetahuan. Sains sebagai suatu proses penelusuran umumnya merupakan suatu pandangan yang menghubungkan gambaran sains yang berkaitan erat dengan kegiatan laboratorium beserta perangkatnya. Pembelajaran sains siswa dituntut untuk belajar aktif siswa yang terimplikasikan dalam kegiatan secara fisik ataupun mental, tidak hanya mencakup aktivitas hands-on tetapi juga minds-on, untuk mendukung pembelajaran fisika yang sesuai dengan hakikatnya, laboratorium memegang peranan yang sangat penting dalam meningkatkan hasil belajar siswa [1].

Proses pembelajaran yang berpusat pada guru, mengakibatkan pembelajaran fisika akhirnya agak membosankan dan menjadikan siswa cepat merasa jenuh sehingga tidak ada ketertarikan siswa untuk mempelajarinya. selama ini pembelajaran fisika di dalam kelas lebih didominasi oleh kegiatan guru dengan metode ceramah dan pemberian tugas pada siswa, sedangkan kegiatan siswa lebih banyak diam dan mendengarkan penjelasan guru, mencatat hal-hal yang dianggap penting dan mengerjakan tugas yang diberikan oleh guru, sehingga keaktifan siswa pada saat proses pembelajaran kurang maksimal. Pada pembelajaran fisika juga jarang sekali siswa didorong untuk menyelesaikan masalahmasalah riil, melalui konsep-konsep yang sudah dipelajari. Akibatnya, konsep yang dimiliki siswa tidak bertahan lama dan hasil belajar siswaa yang tidak maksimal [2].

Praktikum dalam pembelajaran fisika merupakan suatu rangkaian kegiatan pembuktian dan pengembangan konsep fisika yang telah dipelajari secara abstrak melalui buku, internet dan pembelajaran di kelas. Hal ini perlu dilakukan dengan harapan selain memiliki pengetahuan yang bersifat abstrak, siswa juga memiliki pengalaman penerapan pengetahuan secara nyata berupa praktikum yang dilakukan di sekolah, sehingga yang terjadi bukan hanya sebatas mengingat ilmu pengetahuan, namun lebih pada pemahaman terhadap ilmu pengetahuan tersebut.

Belajar dengan menggunakan alat praktik memberi kesempatan kepada siswa untuk dapat melihat dan membuktikan teori yang telah dipelajari, melalui pengamatan dan percobaan secara langsung. Hal ini tentunya akan meningkatkan kreativitas, dan keterampilan serta hasil belajar dapat maksimal. Dengan demikian akan lebih termotivasi dalam mengkaji suatu teori, dan secara tidak langsung rasa keingintahuan juga turut berkembang dan lebih besar dalam proses belajar. 
Fisika tidak terlepas dari praktikum, kegiatan praktikum merupakan salah satu proses pembelajaran dimana siswa terlibat langsung dalam prosesnya, sehingga siswa dapat lebih memahami materi yang di ajarkan. Faktanya bahwa pelajaran yang sulit jika hanya dijelaskan menggunakan teori saja, ingatan hanya dalam jangka pendek. Masalah lain yang muncul adalah banyaknya yang mengalami kesalahan persepsi. Hal ini sesuai dengan yang disebutkan, bahwa dengan pengalaman yang didapatkan secara langsung melalui praktikum, kemungkinan kesalahan persepsi akan dapat dihindari [3].

Penelitian mengenai penggunaan teknologi informasi dan komunikasi dalam pembelajaran fisika menunjukan bahwa meningkatnya hasil pembelajaran yang signifikan. Penggunaan teknologi informasi dan komunikasi ini akan optimal dalam pembelajaran fisika, apabila guru dapat meningkatkan kemampuan profesionalnya sebagai pengguna produk teknologi ini. Dalam pembelajaran fisika, guru dapat memadukan penggunaan laboratorium nyata dengan laboratorium maya (virtual) sehingga hasil belajar siswa menjadi maksimal. [4].

Sesuai dengan apa yang di paparkan di atas dan mengingat betapa pentingnya praktikum dalam proses pembelajaran fisika agar siswa dapat meningkatkan hasil belajar tidak hanya melalui teori saja melainkan dengan praktikum dengan berbantuan media (komputer). Hal inilah yang melatar belakangi peneliti untuk melakukan penelitian sebagai upaya untuk mengetahui pengaruh hasil belajar fisika siswa dengan menggunakan pembelajaran kooperatif tipe STAD dengan bantuan komputer pada siswa kelas X SMA Negeri 1 Parigi.

\section{METODE PENELITIAN}

Jenis penelitian yang digunakan adalah jenis penelitian eksperimen kuasi. Adapun desain penelitian yang digunakan adalah nonequivalen control group design. Desain ini hampir sama dengan pretest-posttest control group design. Desain penelitian yang digunakan seperti pada Tabel 1 [5].

TABEL 1. NONEQUIVALEN CONTROL GROUP DESIGN

\begin{tabular}{cccc}
\multicolumn{4}{c}{ TABEL 1. } \\
\hline Kelompok & Pretest & Perlakuan & Posttest \\
\hline Eksperimen & $\mathrm{O}_{1}$ & $\mathrm{X}$ & $\mathrm{O}_{2}$
\end{tabular}

Kontrol

$\mathrm{O}_{1}$

$\mathrm{O}_{2}$
Keterangan:

$X$ : Perlakuan untuk kelompok eksperimen dengan menerapkan pembelajaran Kooperatif tipe STAD dengan bantuan komputer.

$\mathrm{O}_{1}$ : Tes awal (preetest)

$\mathrm{O}_{2}:$ Tes akhir (postest)

Populasi pada penelitian ini adalah seluruh siswa kelas X IPA di SMAN 1 Parigi dengan kelas $X$ IPAa sebagai kelas kontrol yang siswanya mengikuti model pembelajaran kooperatif tipe STAD dan kelas X IPAb sebagai kelas eksperimen yang siswanya mengikuti model pembelajaran kooperatif tipe STAD dengan bantuan komputer.

Pengambilan sampel dilakukan menggunakan teknik purposive sampling yaitu teknik pengambilan sampel berdasarkan pertimbangan tertentu. Instrumen yang akan digunakan pada penelitian ini ialah tes untuk melihat hasil belajar fisika. Tes tersebut digunakan untuk mengetahui pengaruh hasil belajar fisika siswa pada kelas yang menjadi sampel penelitian. Tes berbentuk pilihan ganda yang dilaksanakan sebanyak dua kali yaitu diawal (preetest) dan akhir (posttest) perlakuan. Intrumen yang digunakan dalam tes akhir (posttest). Tes ini sebelumnya telah di validasi terlebih dahulu oleh validator ahli dan telah diuji coba lapangan.

Analisis data dilakukan dengan menganalisis instrumen terlebih dahulu menggunakan uji validitas item dan reliabilitas tes yang kemudian dengan menganalisis data hasil penelitian menggunakan uji normalitas, uji homogenitas dan uji hipotesis.

\section{HASIL DAN PEMBAHASAN}

Tujuan penelitian ini untuk mengetahui pengaruh pembelajaran kooperatif tipe STAD dengan bantuan komputer terhadap hasil belajar fisika siswa kelas X SMA Negeri 1 Parigi. Data hasil belajar fisika diperoleh melalui tes. Tes yang digunakan yaitu tes pilihan ganda dengan jumlah 20 soal. Pada awal penelitian kedua kelas terlebih dahulu diberikan tes awal. Data tes awal digunakan untuk mengetahui bahwa kedua data berasal dari varians yang sama (homogen) atau memiliki kemampuan yang sama. Skor hasil belajar siswa diperoleh dari tes awal dan tes akhir yang dilakukan pada masing-masing kelas yaitu eksperimen dan kontrol. Nilai rata-rata tes awal dan tes akhir dari kedua kelas dapat dilihat pada Tabel 2 . 
TABEL 2. NILAI TES HASIL BELAJAR TES AWAL DAN TES AKHIR

\begin{tabular}{lcccc}
\hline & Minimum & Maximum & $\begin{array}{c}\text { Rata- } \\
\text { rata }\end{array}$ & $\begin{array}{c}\text { Std. } \\
\text { Deviasi }\end{array}$ \\
\hline $\begin{array}{l}\text { Hasil Tes } \\
\text { Awal Kelas } \\
\begin{array}{l}\text { Eksperimen } \\
\text { Hasil Tes }\end{array}\end{array}$ & 3 & 14 & 7,35 & 3,11 \\
$\begin{array}{l}\text { Akhir Kelas } \\
\text { Eksperimen }\end{array}$ & 8 & 19 & 12,82 & 3,07 \\
$\begin{array}{l}\text { Hasil Tes } \\
\text { Awal Kontrol }\end{array}$ & 1 & 12 & 6,27 & 2,88 \\
$\begin{array}{l}\text { Hasil Tes } \\
\text { Akhir Kontrol }\end{array}$ & 7 & 18 & 11,65 & 2,98 \\
\hline
\end{tabular}

Berdasarkan Tabel 2 dapat dilihat bahwa secara kuantitas untuk tes awal dan tes akhir terdapat perbedaan hasil belajar fisika siswa pada materi elastisistas antara kelas eksperimen dan kelas kontrol. Hasil pengolahan data ini selanjutnya digunakan untuk menganalisis data melalui uji normalitas, uji homogenitas dan uji hipotesis. Data yang akan diuji normalitas adalah data hasil Pretest pada kelas eksperimen dan kelas kontrol. Hasil perhitungan analisis uji normalitas Pretest menggunakan uji normalitas dapat dilihat pada Tabel 3.

TABEL 3 NORMALITAS DISTRIBUSI TES AWAL DAN TES AKHIR PADA KELAS EKSPERIMEN DAN KELAS KONTROL

\begin{tabular}{|c|c|c|c|c|c|c|}
\hline \multirow[b]{2}{*}{ Uraian } & \multicolumn{3}{|c|}{ Tes awal } & \multicolumn{3}{|c|}{ Tes akhir } \\
\hline & $\begin{array}{c}\text { Nilai } \\
X^{2} \text { hituna }\end{array}$ & $\begin{array}{l}\text { Nilai } \\
\mathrm{X}^{2} \text { tabel }\end{array}$ & $\underset{n}{\text { keputusa }}$ & $\begin{array}{c}\text { Nilai } \\
X^{2} \text { hitung }\end{array}$ & $\begin{array}{l}\text { Nilai } \\
\mathrm{X}^{2} \text { tabel }\end{array}$ & $\begin{array}{c}\text { keputusa } \\
\mathrm{n}\end{array}$ \\
\hline $\begin{array}{l}\text { Kelas } \\
\text { Eksperi } \\
\text { men }\end{array}$ & 4,05 & 7,81 & $\begin{array}{l}\text { Terdistri } \\
\text { busi } \\
\text { normal }\end{array}$ & 2,04 & 7,81 & $\begin{array}{l}\text { Terdistri } \\
\text { busi } \\
\text { normal }\end{array}$ \\
\hline $\begin{array}{l}\text { Kelas } \\
\text { Kontrol }\end{array}$ & 1,99 & 7,81 & $\begin{array}{l}\text { Terdistri } \\
\text { busi } \\
\text { normal }\end{array}$ & 2,36 & 7,81 & $\begin{array}{l}\text { Terdistri } \\
\text { busi } \\
\text { normal }\end{array}$ \\
\hline
\end{tabular}

Berdasarkan hasil uji normalitas pada Tabel 3 , diketahui nilai $X^{2}$ Hitung $<X^{2}$ tabel baik itu data tes awal maupun tes akhir sehingga dapat disimpulkan bahwa keduanya berasal dari populasi yang terdistribusi normal.

Perolehan Uji homogenitas pada penelitian ini menggunakan $u j i$ statistik $F$ dengan taraf signifikansi $a=0,05$ dan untuk pretest nilai varians kelas eksperimen sebesar 9,58 serta kelas kontrol sebesar 9,30. Berdasarkan hasil perhitungan, diperoleh nilai $F_{\text {hitung }}$ sebesar 1,03 sedangkan nilai $F_{\text {tabel }}$ sebesar 1,98. Sedangkan, untuk posttest nilai varians kelas eksperimen sebesar 9,50 serta kelas kontrol sebesar 8,54. Berdasarkan hasil perhitungan, diperoleh nilai

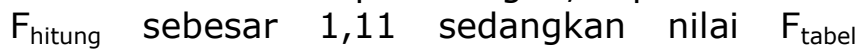
sebesar 1,98. Berdasarkan hasil ini dapat disimpulkan bahwa data hasil pretest dan posttest pada kelas eksperimen dan kontrol memiliki varians homogen.

Karena data memenuhi syarat normal dan homogen, maka dilakukan pengujian hipotesis menggunakan uji-t (uji dua pihak). Diketahui $t_{\text {hitung }} \geq t_{\text {tabel }}$ atau $4,80 \geq 2,01$. Hal ini berarti, nilai $t_{\text {hitung }}$ berada di luar daerah penerimaan $\mathrm{HO}$. Dengan demikian $\mathrm{HO}$ ditolak dan $\mathrm{H} 1$ diterima, dan dapat disimpulkan bahwa terdapat perbedaan rata-rata hasil belajar fisika antara kelompok siswa yang mengikuti pembelajaran kooperatif tipe STAD dengan bantuan komputer dengan siswa yang mengikuti pembelajaran kooperatif tipe STAD. Dengan kata lain, nilai hasil belajar fisika siswa kelas eksperimen lebih tinggi dibanding dengan kelas kontrol.

Pada Hasil uji peningkatan hasil belajar fisika siswa antara kelas eksperimen dan kelas kontrol. Untuk kelas eksperimen diperoleh $\mathrm{N}$ gain rata-rata $12,81 \%$, dan kelas kontrol diperoleh $\mathrm{N}$-gain $11,65 \%$. Kelas eksperimen termasuk dalam kategori sedang, dengan nilai $\mathrm{g}>30$ dan juga kelas kontrol termasuk dalam kategori sedang, dengan nilai $\mathrm{g}>30$. Kedua kelas ini mengalami peningkatan, namun peningkatan lebih besar terjadi pada kelas eksperimen. Walaupun dari kriteria $\mathrm{N}$-gain sendiri keduanya termasuk dalam kategori sedang. Berdasarkan hasil yang diperoleh, terlihat bahwa pada kelas eksperimen hasil belajar fisika siswa mengalami kenaikan yang lebih tinggi dari pada kelas kontrol setelah diberi perlakuan berupa proses belajar mengajar menggunakan model pembelajaran kooperatif tipe STAD dengan bantuan komputer.

Pada kelas eksperimen dilakukan sebuah pengajaran dengan menjadikan siswa sebagai peran utama dalam sebuah proses belajar mengajar, dimana siswa yang akan lebih aktif dalam pembelajaran dan memecahkan masalah yang diberikan dan guru hanya sebagai fasilitator. Ditambah dengan menggunakan bantuan komputer yaitu berupa kegiatan praktikum yang dilakukan dengan sangat modern dalam bentuk alat PASCO membuat proses belajar mengajar dikelas lebih aktif dan menyenangkan sehingga siswa akan lebih tertarik untuk mengikuti pembelajaran dan mudah memahami materi yang diajarkan. Selain itu, dalam proses belajar mengajar yang dilakukan dikelas ini juga menggunakan sistem kerja kelompok dalam menyelesaikan masalah yang diberikan oleh guru dan dirangkai dalam bentuk LKS. Hal ini dilakukan agar terdapat interaksi antar siswa yang nantinya akan membuat siswa akan saling bertukar pendapat dan pikiran untuk mendapatkan solusi terbaik dalam menyelesaikan masalah yang diberikan, kemudian hasil pemikiran dari kelompok tersebut dirangkai menjadi satu dan dipresentasikan didepan kelas. Setelah perwakilan kelompok memaparkan hasil kerja 
kelompoknya, kelompok lain diberi kesempatan untuk bertanya atau menanggapinya, sehingga terdapat interaksi antar siswa dalam satu kelas. Hal inilah yang membuat siswa lebih cepat menyerap materi pelajaran yang diajarkan. Adapun materi yang diajarkan adalah elastisitas. Siswa yang tadinya pasif dalam pembelajaran dengan menerapkan model pembelajaran ini, siswa menjadi bersemangat dan lebih fokus pada pembelajaran.

Hasil Penelitian ini sejalan dengan penelitian yang telah dilakukan sebelumnya yang berhasil menunjukan bahwa penggunaan teknologi informasi dan komunikasi dalam pembelajaran fisika menunjukan bahwa meningkatnya hasil pembelajaran yang signifikan. Penggunaan teknologi informasi dan komunikasi ini akan optimal dalam pembelajaran fisika, apabila guru dapat meningkatkan kemampuan profesionalnya sebagai pengguna produk teknologi ini. Dalam pembelajaran fisika, guru dapat memadukan penggunaan laboratorium nyata dengan laboratorium maya (virtual) sehingga hasil belajar siswa menjadi maksimal.

Peningkatan rata-rata hasil belajar pada siklus II cukup signifikan karena secara individu siswa yang mencapai ketuntasan belajar meningkat dari 13 siswa menjadi 38 siswa. Pemahaman siswa meningkat dari $60 \%$ siswa yang dinyatakan tidak paham pada siklus I menjadi $5 \%$ siswa yang dinyatakan tidak paham pada siklus II, hasil analisis tanggapan siswa terhadap pengajaran diperoleh rata-rata tanggapan siswa sebelum tindakan sebesar $72,90 \%$. Setelah tindakan, nilai rata-rata tanggapan siswa meningkat menjadi $76,81 \%$. Secara keseluruhan nilai yang diperoleh untuk setiap indikator dalam angket mengalami peningkatan. Jadi, penerapan metode pembelajaran inkuiri terbimbing dengan berbantuan multimedia dapat meningkatkan minat dan pemahaman siswa kelas $X-I$ semester 2 SMAN 14 Semarang [6].

Berdasarkan semua data yang telah dijabarkan dapat disimpulkan bahwa, terdapat pengaruh pembelajaran kooperatif tipe STAD dengan bantuan komputer terhadap hasil belajar fisika siswa kelas X SMA Negeri 1 Parigi.

Kelebihan dari model pembelajaran ini adalah keaktifan siswa. Melalui model pembelajaran ini siswa dilibatkan untuk aktif berpikir dan menemukan secara langsung pengertian atau konsep yang ingin diketahuinya. Kecil kemumgkinan terjadi kesalahan pada siswa karena mereka terlibat langsung dalam proses pengamatan sehingga proses pembelajaran terlaksana dengan benar dan sesuai dengan tahap-tahap praktikum. Adapun kekurangan dalam model pembelajaran ini adalah guru harus sabar membimbing siswa agar menemukan sendiri pengertian atau konsep dari materi yang ingin diketahuinya. Selain itu, kekurangan lain dalam menggunakan model pembelajaran ini adalah guru bergantung pada listrik dalam menggunakan medianya, karena menggunakan komputer/laptop, dan juga alat praktikum yang cukup mahal sehingga tidak smua sekolah bisa mendapatkan alat praktikum modern seperti ini.

\section{KESIMPULAN DAN SARAN}

Berdasarkan hasil penelitian dan analisa data menggunakan uji-t pada taraf signifikansi $5 \%$ dan $\mathrm{dk}=50$, dengan uji prasyarat normalitas dan homogenitas. Pengujian hipotesis menggunakan uji-t, dari hasil perhitungan statistic didapatkan harga $t_{\text {hitung }}$ sebesar 4,80 dan $t_{\text {tabel }}$ pada taraf signifikansi $5 \%$ dan $\mathrm{dk}=50$ adalah 2,01. Sehingga $H_{1}$ diterima dan $H_{0}$ ditolak. Berdasarkan hasil ini dapat disimpulkan bahwa hasil belajar fisika siswa yang diberi perlakuan pembelajaran kooperatif tipe STAD dengan bantuan komputer lebih tinggi dari pada hasil belajar fisika siswa yang mendapatkan pembelajaran kooperatif tipe STAD pada kelas $X$ SMA Negeri 1 Parigi.

Adapun saran yang dapat dikemukakan adalah: (1) Perlu adanya menejemen waktu yang baik dalam proses praktikum di laboratorium sehingga memudahkan guru dan siswa dalam melaksanakan tahap-tahap pembelajaran di laboratorium, sehingga mampu memanfaatkan ketersediaan waktu yang ada dalam pembelajaran. (2) Untuk mendapatkan hasil penelitian yang lebih baik, sebaiknya sebelum melakukan penelitian, pada kelas yang akan menggunakan model pembelajaran kooperatif tipe STAD dengan bantuan komputer dilakukan pembiasaan penerapan kooperatif tipe STAD terlebih dahulu. Misalnya, dalam beberapa pertemuan sebelum penelitian, dan juga perkenalan alat-alat praktikum sehingga pada waktu penelitian mereka sudah terbiasa dan tidak kesulitan mengikuti proses pembelajaran khususnya dalam pelaksanaan praktikum. (3) Perlu adanya angket aktivitas siswa untuk menunjang keterlaksanaan pembelajaran siswa di kelas maupun di laboratorium.

\section{DAFTAR PUSTAKA}

[1] Katili, S.N., Sadia, W.I. dan Suma, K. (2013). Analisis Sarana dan Intensitas Penggunaan Laboratorium Fisika Serta Kontribusinya Terhadap Hasil Belajar Siswa SMA Negeri di Kabupaten Jembrana. Dalam eJournal Program Pascasarjana Universitas Pendidikan Ganesha [Online],

Vol 
3Tahun2013.Tersedia:http://pasca.undiksha.ac.id/ejo urnal/index.php/jurnalipa/article/download/795/580.ht $\mathrm{ml}[11$ oktober 2013].

[2] Siswanto, R. 2001. Pengaruh Model Pembelajaran Kooperatif Tipe Nht(Numbered Hends Together) Menggunakan Peta Konsep Dan Peta Pikiran Terhadap Penalaran Formal Siswa. Skripsi Pada Fakultas Ikip Pgri Semarang : diterbitkan.

[3] Sanjaya, W. 2006. Strategi Pembelajaran. Jakarta: Kencana Prenada Media Group

[4] Sardianto, M, S. 2012. Penggunaan Teknologi Informasi Dan Komunikasi Dalam Pembelajaran Fisika. Palembang.

[5] Sugiyono, (2008). Statistik untuk Penelitian. Bandung: Alfabeta.

[6] Wahyudin, S. 2010. Keefektifan Pembelajaran Berbantuan Multimedia Menggunakan Metode Inkuiri Terbimbing Untuk Meningkatkan Minat Dan Pemahaman Siswa. Jurusan Fisika, FMIPA Universitas Negeri Semarang, Semarang, Indonesia: diterbitkan. 